\title{
Modowe freaki i backpakerzy. Najnowsze anglicyzmy na polskich blogach
}

\section{Modowe freaki and backpakerzy. Newest loan words on polish blogs}

\author{
Anna Mękarska, Victoria Kamasa \\ INSTYTUT J ĘZYKOZNAWSTWA, UNIWERSYTET IM. ADAMA MICKIEWICZA \\ AL. NIEPODLEGŁOŚCI 4, 61-874 POZNAŃ \\ vkamasa@amu.edu.pl
}

\begin{abstract}
Blogs are continuously gaining on popularity and social influence in Poland. In this paper we analyze the use of newest English loan words on corpus of texts from most influential Polish blogs. To present complex picture of the loan words, we describe them among others according to their current status as loan words and semantic fields they belong to. The results show some tendencies in the newest English loan words in Polish.
\end{abstract}

\section{Wprowadzenie}

Celem niniejszego tekstu jest opis i klasyfikacja anglicyzmów występujących na wybranych polskich blogach. Zidentyfikowane anglicyzmy poddane zostaną analizie ilościowej i jakościowej. Opisywane badania mają charakter pilotażowy i stawiają sobie za cel określenie najnowszych tendencji $\mathrm{w}$ dotyczących zapożyczeń $\mathrm{z}$ angielskiego $\mathrm{w}$ polszczyźnie.

\section{Blog jako przedmiot badań}

Z roku na roku rośnie popularność blogów, nazywanych także pamiętnikami internetowymi. Badania przeprowadzone przez CBOS wskazują, ze w 2012 roku niemal połowa użytkowników Internetu czytała blogi (Feliksiak 2012). To około $20 \%$ więcej niż zaledwie pięć lat temu. Z cytowanych badań wynika równiė̇, że wraz z rosnącą popularnością blogów spada czytelnictwo gazet (Feliksiak 2012). 
Sam blog to stosunkowo nowy gatunek tekstu, który pojawił się w Polsce prawdopodobnie w 2000 roku. Była to odpowiedź na podobne strony w Stanach Zjednoczonych, Wielkiej Brytanii, Kanadzie i J aponii (Kawka 2010: 61). Aby założyć blog i go prowadzić nie jest potrzebna znajomość HTML, ani żadnego innego języka programowania czy projektowania stron WWW - nie dziwi więc fakt, że w Polsce istnieje około 3 milionów internetowych pamiętników. Jak już wspomniano, poziom czytelnictwa blogów jest również bardzo wysoki, zwłaszcza w porównaniu z formami tradycyjnego kontaktu ze słowem pisanym, w tym z czytaniem książek: „Miesięczny zasięg blogów na początku 2007 roku przekroczył 40\% widowni internetowej, a w marcu wyniósł ponad 42\%” (Kawka 2010: $64)$.

Próba zdefiniowania czym jest blog nie jest łatwym zadaniem, ponieważ jest to gatunek, który ciągle się kształtuje i przybiera ciągle nowe formy. Według definicji Crystala (2006), blogi moga być prywatnymi pamiętnikami, obejmującymi zarówno krótkie notatki jak i długie eseje. Wiele z nich dotyczy ogólnych zainteresowań, takich jak hobby czy sprawy polityczne (Crystal 2006: 15). Z kolei według Meyersa (2009), który zajmuje się badaniem dyskursu blogów, ten gatunek to: „rodzaj tekstu, który jest zdefiniowany nie tyle co przez swoją formę czy zawartość, co przez rodzaje zastosowań oraz sposoby, w których to zastosowanie buduje społeczność, tożsamość i wspólnotę"1 (Myers 2009: 15).

W literaturze można spotkać dwa główne podejścia do klasyfikacji gatunkowej blogów:

a) uznanie za gatunek internetowy taki jak forum internetowe, czy poczta elektroniczna (np. Maj 2010);

b) porównanie do tradycyjnych gatunków tekstu, takich jak artykuł czy dziennik (np. Kozanecki 2010).

Sobczak (2010) podsumowuje dyskusję na temat przynależności gatunkowej blogów następująco:

„popularność blogów, zarówno wśród osób tworzących takie przekazy, jak i wśród czytelników, wynika z wielu przyczyn. Niezależnie od tego, czy uznamy blog za pamiętnik bądź dziennik, czy tė̇ uznamy, że to swoisty, nowy gatunek dziennikarski lub literacki - niewątpliwie u jego podstaw leżą pewne tendencje i uwarunkowania ekshibicjonistyczne, od których nie jest wolny żaden memuarysta ani większość pisarzy. Innymi ważnymi przyczynami tego typu ekspresji wydaje się próba „odegrania” się na rzeczywistych bądź urojonych wrogach, zaistnienia w społeczeństwie, „rozliczenia się" $\mathrm{z}$ przeszłością, a wreszcie - zamiar przekazania szerszemu ogółowi prawd znanych tylko piszącemu" (Sobczak, 2010:193).

\footnotetext{
${ }^{1}$ Tłumaczenie autorek.
} 
Anna Mękarska, Victoria Kamasa: Modowe freaki i backpakerzy. Najnowsze anglicyzmy na polskich blogach

Jeżeli chodzi o pochodzenia słowa blog, to jest to „skrót od słowa weblog. Weblog - [...] stanowi zbitek dwóch angielskich wyrazów: web sieć, przez Anglosasów używanego zamiennie ze słowem internet, i log, który przed epoką komputeryzacji najczęściej kojarzony był z dziennikiem okrętowym" (Olszański 2006: 34). Jako pierwszy słowa weblog użył J ohn Barger, redaktor jednego z pierwszych internetowych dzienników, znanego pod nazwą Robot Wisdom. Podczas kiedy słowo weblog zostało po raz pierwszy użyte w 1997 roku, dwa lata później pojawiła się skrócona i funkcjonująca obecnie wersja tego słowa, czyli blog. Została ona użyta na stronie Petera Merholza, który postanowil podzielić wyraz na dwa człony: we blog (my blogujemy) (Olszański 2006: 34).

J edną z kluczowych różnic pomiędzy tradycyjnymi mediami a blogami są ich autorzy. O ile, aby pisać do gazety zwykle potrzebne jest kierunkowe wyższe wykształcenie, to w przypadku blogów każdy użytkownik Internetu może stać się twórcą treści. Dlatego to właśnie blogi są źródłem materiału językowego wykorzystanego w prezentowanym badaniu - pozwalają one na bliższe przyjrzenie się tendencjom rozwojowym współczesnej polszczyzny. Oto bowiem możemy zaobserwować język ludzi młodych, będących adresatami kultury masowej, chętnie korzystających z modnych dziś anglicyzmów. „Popularne blogi potrafią przyciągnąć więcej czytelników niż niejedna gazeta. W połączeniu $\mathrm{z}$ dużo większą interaktywnością można powiedzieć, że ich wpływ na rozwój języka jest coraz większy i zaczyna prześcigać tradycyjne media” (Crystal 2006: 246).

Nie bez znaczenia dla formy bloga, a także języka na nim używanego pozostaje fakt używania Internetu jako środka komunikacji. Wytwarza on specyficzną sytuację między nadawcą a odbiorcą komunikatu, daje możliwość szybkiego przepływu informacji, pozwala każdemu na publikowanie własnych tekstów, które często nie podlegają korekcie. Biorąc pod uwage fakt, że do badania zostały wybrane jedne $\mathrm{z}$ najpopularniejszych blogów w Polsce, a ich popularność często pobija rankingi czytelnictwa wielu polskich gazet, można w ich przypadku prawdopodobnie mówić o wpływie na społeczeństwo podobnym do tego wywieranego przez tradycyjne media.

\section{Zapożyczenia jako przedmiot badań}

Inną emanacją zmian społecznych i cywilizacyjnych są zmiany językowe, a jednym z przykładów takich zmian są zapożyczenia. Jak stwierdza Thomason (2001) nie ma żadnego dowodu na to, że jakikolwiek język rozwinął się w kompletnej izolacji od innych języków. W literaturze przedmiotu można znaleźć wiele ogólnych definicji zapożyczenia. Według Słownika Terminologii Językoznawczej (1968) pożyczka to „element zapożyczony z obcego języka. Najczęściej są to wyrazy [...], rzadziej afliksy, które dostają się za pośrednictwem wyrazów obcych [...], ale bywają również zapożyczenia strukturalne, czyli tzw. kalki językowe”. Z kolei Thomason i Kaufan (1991) ze względu na swoje zainteresowani kontaktami między językami i kreolami zdefiniowali zapożyczenie jako „wcielenie 
obcych cech w grupę języka natywnego przez rozmówców tego języka: język natywny jest zachowany, ale jest zmieniony przez dodanie włączonych cech”2. Powyższa definicja skupia się na użytkowym aspekcie języka, nie zawiera informacji o rodzajach zapożyczeń czy obszarach wpływu obcych form. Z kolei Witaszek-Samborska (1992) w swoich badaniach nad zapożyczeniami podkreśla, że „za zapożyczenie uważa się wszystkie wyrazy przejęte $z$ języków obcych do polszczyzny [...] bez względu na czas zapożyczenia, stopień przyswojenia oraz stopień poczucia ich obcości w świadomości społecznej”. Ta definicja nie uwzględnia jednak zapożyczeń w zakresie składni i morfologii. Warto przywołać tu również stanowisko Haugena (1950), według którego badanie relacji między poszczególnymi językami to „próba odtworzenia w danym języku wzorców wcześniej zaczerpniętych z innego języka"3.

W związku z planowaną w prezentowanych badaniach analizą różnych typów zapożyczeń potrzebne jest wybranie definicji ogólnej, którą można będzie odnieść do typu różnych odmian tego zjawiska. Definicja sformułowana przez Haugena spelnia to kryterium. W swojej pracy zwrócił uwagę, że użyta tam słowo reproduction (pl. kopiowanie, odtwarzanie), nie ma na celu sugerowania, że wyrazy zapożyczone to mechanicznie przeniesione do innego języka imitacje wyrazów z języka oryginalnego. Procesy towarzyszące powstawaniu zapożyczeń są różne, tak jak ich efekty (Haugen 1950).

Podejmowany tutaj temat zapożyczeń z angielskiego w polszyźnie doczekał się już wielu opracowani w literaturze. Pierwsze z nich pochodzą z lat trzydziestych ubiegłego wieku (np. H. Konieczna 1936/1937), na dużą uwagę również zasługują opracowania J acka Fisiaka (1962a, 1962b) z lat sześćdziesiątych. Większość prac poświęconych zapożyczeniom pochodzi jednak z ubiegłego wieku oraz dotyczy anglicyzmów udokumentowanych już w słownikach języka polskiego. Do jednej z niewielu prac dotyczących najnowszych zapożyczeń należy artykuł Doroty Zdunkiewicz-J edynak „Spolszczony angielski czy zangielszczony polski? Wpływ języka angielskiego na język generacji gadu-gadu" (2008). Autorka prowadzi badania z perspektywy zbliżonej do tej przyjmowanej w prezentowanej pracy, zajmuje się bowiem badaniem zapożyczeń pojawiających się między innymi na blogach. Do analizy zapożyczeń używa słownika najmłodszej polszczyzny B. Chacińskiego (2005) oraz innych tego typu słowników funkcjonujących w Internecie. Analizuje ona 70 wyrazów lub związków frazeologicznych, których znajomość została potwierdzona przez grupę młodych użytkowników polszczyzny w wieku 15-20 lat. W odróżnieniu jednak od prezentowanych tutaj badań, Zdunkiewicz-J edynak zaznacza, że wyróżnione przez nią anglicyzmy nie mogą być innowacjami językowymi, co również weryfikuje w ankiecie. Celem jej pracy jest określenie wpływów anglicyzmów, przyjrzenie się typowym procesom zapożyczania oraz stosunkom młodych Polaków do języka angielskiego i do polszczyzny.

2 Tłumaczenie autorek.

3 Tłumaczenie autorek. 
Anna Mękarska, Victoria Kamasa: Modowe freaki i backpakerzy. Najnowsze anglicyzmy na polskich blogach

Innym przykładem badań nad zapożyczeniami jest praca Agnieszki Stępkowskiej „English Loanwords in Polish Naval Vocabulary” (2011). W odróżnieniu od prezentowanych tutaj badań, uwaga autorki skupiona jest na zapożyczeniach, które powstały w różnych okresach czasu. Dodatkowo większość omawianych zapożyczeń pochodzi ze słowników specjalistycznych. Celem pracy Stępkowskiej jest zebranie jak największej liczby zapożyczeń oraz opisanie ich pochodzenia i umiejscowienie ich na tle historycznym. Warto zauważyć, że autorka nie zajmuję się tylko anglicyzmami, ale również zapożyczeniami z różnych języków, co wynika z charakteru jej badań (kontakty marynarzy z różnymi nacjami).

Najbardziej zbliżone do prezentowanych tutaj badań prowadzi Hanna Wiśniewska-Białaś w swojej rozprawie doktorskiej „Wpływ języka angielskiego na polszczyznę blogów" (2011). Autorka chce określić charakter i stopień wpływu języka angielskiego na polszczyznę blogów w sferze leksyki, semantyki i składni na przestrzeni ostatnich lat. Od prezentowanych tutaj badań odróżnia ją jednak sposób wykorzystania Narodowego Korpusu J ęzyka Polskiego (NKJ P)²: nie wyklucza zapożyczeń odnotowanych w NKJP, wykorzystuje go natomiast do badania ugruntowania danego anglicyzmu w języku polskim. Uwage zwraca również fakt, że choć badania zostały przeprowadzone zaledwie trzy lata temu, ich wyniki już znacznie się różnią od tych przedstawionych $\mathrm{w}$ niniejszej pracy. Świadczy to o niesamowitej szybkości z jaką zmienia się język w Internecie, co jest znakomitym dowodem na to, że przeprowadzenie takich badań jest potrzebne i może prowadzić do pokazania najnowszych zmiany w języku polskim.

\section{Metody}

\subsection{Materiał badawczy}

Materiał badawczy stanowi korpus blogów, w skład którego wchodzą teksty napisane w listopadzie 2012 roku na 1o wybranych blogach. Blogi zostały wybrane na podstawie rankingu „Najbardziej wpływowi blogerzy Polski w 2012 r." opracowanego przez Tomka Tomczyka - autora jednego z najbardziej popularnych blogów w Polsce. Raport ten został opublikowany na jego blogu (Tomczyk 2012). Do badania została wybrana „złota dziesiątka" rankingu. Przy wyborze blogów, autor zestawiania brał pod uwagę: liczbę czytelników bloga określaną przy pomocy statystyk dostępnych na blogu, liczbę komentarzy, liczbę cytowań, linkowań i liczbę publikacji pojawiających się na blogu, a także liczbę publikacji autora blogu w innych mediach (np. w prasie). W rankingu uwzględnione zostały wyłącznie blogi, na których prezentowane są indywidualne opinie, nie zaś przetwarzane cudze. Nie były brane pod uwagę były również blogi firmowe, korporacyjne oraz blogi osób znanych wcześniej z mediów. Za takim

${ }^{4}$ Kwestia ta zostanie bardziej szczegółowo omówiona w sekcji Metody analizy. 
wykluczeniem stało przekonanie, że ich autorzy nie prezentują swoich idei, a często to, co narzuca im pracodawca, od którego są zależni.

Wybrane blogi i ich autorzy oraz dziedzina, której są poświęcone:

$\ddot{y}$ www.blog.mediafun.pl - Maciej Budzich - komentarz, marketing, reklama;

ÿ www.macademiangirl.blogspot.com - Tamara Gonzalez Perea moda;

ÿ www.podrozniccy.com - J akub i Anna Górniccy - podróże;

$\ddot{y}$ www.hatalska.com - Natalia Hatalska - reklama, blogosfera;

$\ddot{y}$ www.segritta.com - Matylda Kozakiewicz - lifestyle;

$\ddot{y}$ www.blog.kurasinski.com - Artur Kurasiński - media;

$\ddot{y}$ www.antyweb.pl - Grzegorz Marczak - Internet, technologie;

$\ddot{y}$ www.kominek.es, www.kominek.in - Tomek Tomczyk - lifestyle;

$\ddot{y}$ fashionelka.pl - Eliza Wydrych - moda, lifestyle.

\subsection{Metody analizy}

Celem prowadzonych badań było przyjrzenie się tendencjom dotyczącym najnowszych zapożyczeń występujących na blogach, dlatego też zastosowano następującą procedurę wyboru poszczególnych zapożyczeń:

1. Z tekstów ręcznie wybrano wszystkie wyrazy lub zwroty, które posiadają przynajmniej jeden angielski morfem leksykalny. Pod uwagę wzięto również leksemy, które posiadają jedynie obcy format prefiksalny lub sufiksalny. W przypadku całych zwrotów dalszej analizie poddano wszystkie zwroty, w których przynajmniej jeden wyraz, z którego złożona jest fraza posiada obce morfemy lub sufiks.

2. Występowanie poszczególnych zapożyczeń sprawdzono $\mathrm{w}$ wersji internetowej Słownika Języka Polskiego [SJ P] (http://sjp.pwn.pl/). $\mathrm{Z}$ dalszej analizy wyeliminowano wszystkie wyrażenia, które występowały w SJP w formie zaobserwowanej w materiale badawczym. Zdecydowano się jednak uwzględnić w dalszych badaniach te wyrażenia, które w SJ P występują jedynie w formie nieodmiennej, zaś na blogach pojawiają się $\mathrm{w}$ formie odmienione. Uwzględniono również te jednostki leksykalne, w których zaszły zmiany w obrębie semantyki wyrazów rodzimych zachodzące pod wpływem języka angielskiego.

3. Występowanie poszczególnych zapożyczeń sprawdzono w Narodowym Korpusie J ęzyka Polskiego. Z dalszej analizy wyeliminowano wszystkie wyrażenia występujące w NKJP częściej niż 50 razy.

Pod uwagę nie były brane teksty piosenek, teksty reklamowe i cytaty pojawiające się na blogach oraz nazwy marek, produktów i firm.

Wybrane w ten sposób anglicyzmy zostały poddane dalszej analizie, na którą składał się: 
Anna Mękarska, Victoria Kamasa: Modowe freaki i backpakerzy. Najnowsze anglicyzmy na polskich blogach

4. Podział zapożyczeń ze względu na kryterium przedmiotu zapożyczenia. Wykorzystano w tym celu typologię zaproponowaną przez Witaszek- Samborską (1992).

5. Podział zapożyczeń ze względu na stopień przyswojenia. Posłużono się tu podziałem zaproponowanym przez Haugena (1968).

6. Podział ze względu na części mowy, do których należą poszczególne zapożyczenia.

7. Podział ze względu na pola semantyczne, do których należą poszczególne zapożyczenia. Zostały one przyporządkowane określonym zakresom pojęciowym na podstawie bazy synonimów (www.slownik-synonimow.eu [data dostępu: maj 2013]).

\section{Wyniki}

\subsection{Przegląd}

Analizie zostało poddane dziesięć blogów, na których łącznie wystąpiło około 70000 słów. Znalezionych i zakwalifikowanych do badania zostało 114 zapożyczeń, na które składały się pojedyncze wyrazy, frazy, idiomy oraz całe zdania. W przypadku wystąpienia zapożyczenia na więcej niż jednym blogu do analizy jakościowej wliczono tylko jedno wystąpienie.

$\mathrm{Na}$ badanych blogach zaobserwowano zróżnicowaną liczbę zapożyczeń. Ze względu na różną częstotliwość pojawiania się wpisów na blogach, a także ich różną długość zanalizowano również liczbę zapożyczeń przypadającą na tysiąc słów (określaną dalej jako częstotliwość). Taka analiza pozwoliła stwierdzić, że jeżeli chodzi o wartości bezwzględne, to największa liczba zapożyczeń pojawiła się na blogu blog.kurasinski.com (28), natomiast największa częstotliwość używania zapożyczeń dotyczy blogi mediafun.pl $(2,9)$. Niewiele rzadziej występują zapożyczenia na blogu poświęconym również technologii - blog.kurasiński.com $(2,8)$. Z kolei najmniejszą częstotliwość występowania zapożyczeń odnotowano na blogach kominek.in $(0,4)$ i kominek.es $(0,2)$, pisanych przez tego samego autora. W tym przypadku można więc przypuszczać, że to autorski styl pisania, a nie poruszana problematyka ma wpływ na liczbę używanych zapożyczeń. Szczegółowe dane dotyczące występowania zapożyczeń na badanych blogach znajdują się w tabeli $\mathrm{nr} 1$. 
Tabela nr 1.: Zapożyczenia na badanych blogach.

\begin{tabular}{cccc} 
NAZWA BLOGA & $\begin{array}{c}\text { LICZBA } \\
\text { SEÓW }\end{array}$ & $\begin{array}{c}\text { LICZBA } \\
\text { ZAPOŹYCZEN }\end{array}$ & $\begin{array}{c}\text { CZESTOTLIWOŚ } \\
\text { Ċ }\end{array}$ \\
\hline antyweb.pl & 8615 & 23 & 2,6 \\
\hline fashionelka.pl & 3310 & 4 & 1,2 \\
\hline hatalska.com & 4886 & 9 & 1,8 \\
\hline kominek.es & 4931 & 1 & 0,2 \\
\hline kominek.in & 7420 & 3 & 0,4 \\
\hline blog.kurasiński.com & 9993 & 28 & 2,8 \\
\hline $\begin{array}{c}\text { macademiangirl.co } \\
\text { m }\end{array}$ & 3625 & 7 & 1,9 \\
\hline mediafun.pl & 7545 & 22 & 2,9 \\
\hline segritta.pl & 5675 & 3 & 0,5 \\
\hline podrozniccy.pl & 10166 & 14 & 1,4 \\
\hline suma & 66166 & 114 & 15,9 \\
\hline średnia & 6616 & 11,4 & 1,6
\end{tabular}

J ak wskazuje zamieszczona poniżej tabela $\mathrm{nr} 2$, w badanym materiale najwięcej zapożyczeń znajduje się na blogach związanych z mediami i technologią, a najmniej na blogach dotyczących stylu życia. Pod uwagę należy jednak wziąć pilotażowy charakter prezentowanych badań: liczba blogów, która poddana została analizie jest niewystarczająca, aby formułować twierdzenia dotyczące zależności między liczbą zapożyczeń a rodzajem blogów ogólnie. Natomiast przedstawiona tu tendencja może stanowić punkt wyjścia do dalszych badań mających na celu jej potwierdzenie.

Tabela nr 2.: Występowanie zapożyczeń ze względu na tematykę blogów.

\begin{tabular}{llll} 
& $\begin{array}{l}\text { ŚREDNIA } \\
\text { LICZBA SŁÓW }\end{array}$ & $\begin{array}{l}\text { ŚREDNIA } \\
\text { LICZBA } \\
\text { ZAPOŻYCZEN }\end{array}$ & $\begin{array}{l}\text { SREDNIA } \\
\text { CZE_STOTLIWOŚĆ }\end{array}$ \\
\hline technologie & 9304 & 25,5 & 2,7 \\
\hline media $^{5}$ & 5787,3 & 10,7 & 1,6 \\
\hline moda & 3467,5 & 5,5 & 1,6 \\
\hline podróże & 10166 & 14 & 1,4 \\
\hline styl życia & 6008,7 & 2,3 & 0,4
\end{tabular}

Na uwagę zasługują dwie bardziej szczegółowe kwestie. Blog podrozniccy.pl zawierał nie tylko same wpisy jego twórców, ale też wiele wywiadów z ludźmi z całego świata, które zostały przetłumaczone przez autorów na język polski. Można przypuszczać, że proces tłumaczenia wiąże się z refleksją nad językiem i sposobem jego używania, co z kolei może modyfikować sposób używania zapożyczeń. Znajduje to potwierdzenie w badanym materiale: na blogu znaleziono 14 zapożyczeń, żadne $\mathrm{z}$ nich jednak nie pojawiło się $\mathrm{w}$ tłumaczeniach. Znacząco obniża to więc

${ }^{5}$ Blog kominek.es został uwzględniony w dwóch kategoriach: styl życia i media. 
Anna Mękarska, Victoria Kamasa: Modowe freaki i backpakerzy.

Najnowsze anglicyzmy na polskich blogach

częstotliwość występowania zapożyczeń na tym blogu. Z kolei w przypadku blogów poświęconych modzie i trendom uwagę zwraca stosunkowo mała średnia liczba słów. Takiej tematyce towarzyszy bardzo duża liczba zdjęć, które w tym wypadku są prawdopodobnie lepszym nośnikiem informacji i wypierają przekaz językowy.

\subsection{Podział zapożyczeń ze względu na kryterium przedmiotu zapożyczenia}

Pośród 114 znalezionych zapożyczeń największą grupę stanowią zapożyczenia właściwe. Odnotowano ich 92, co stanowi 81\% ogółu. Odnotowano również osiem kalek (8\%), dwa zapożyczenia sztuczne (2\%) oraz jedno zapożyczenie semantyczne (1\%). Dokładne proporcje występowania zapożyczeń w badanym materiale zostały przestawione na wykresie $n r 1$.

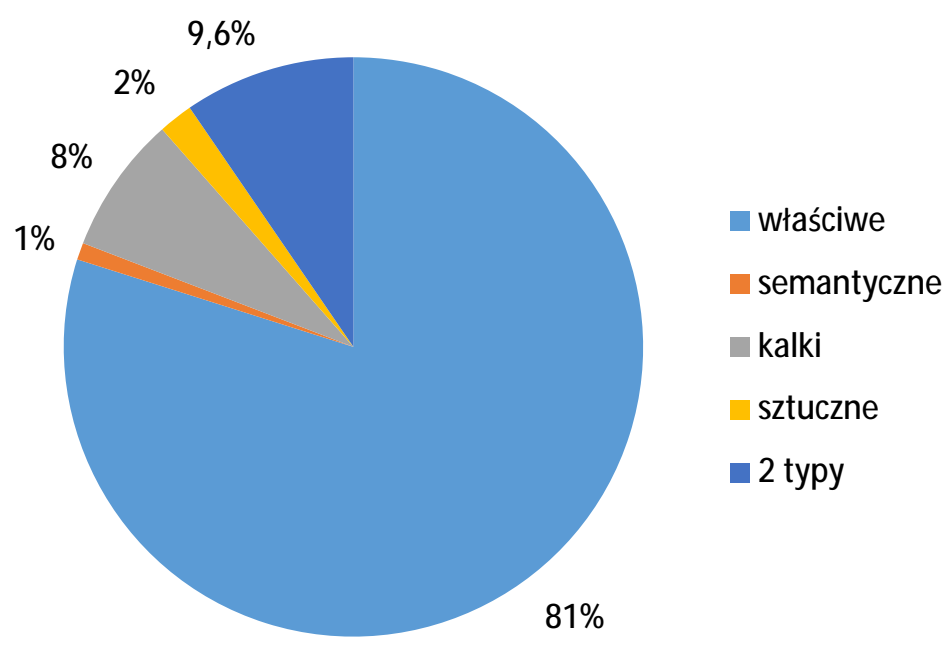

Wykres nr 1.: Podział zapożyczeń ze względu na przedmiot zapożyczania.

Największą grupę stanowią zapożyczenia właściwe, czyli te wyrazy, które zostały przejęte w postaci oryginalnej lub nieznacznie zmienionej. Zapożyczenia znalezione na blogach najczęściej dotyczą:

1. Nazw nowych sprzętów:

ÿ ultrabook - odmiana notebooka i jednocześnie nowa klasa tych urządzeń zdefiniowana przez firmę Intel (www.intel.com [data dostępu: maj 2013]);

$\ddot{y}$ audiobook - nagranie dźwiękowe zawierające odczytany przez lektora tekst (www.wolnelektury.pl [data dostępu: maj 2013]).

2. Technologii: 
$\ddot{y}$ cloud networking - (pol. chmura obliczeniowa) model przetwarzania oparty na użytkowaniu usług dostarczonych przez usługodawcę (www.citrix.com.pl [data dostępu: maj 2013]);

$\ddot{y}$ data center - centrum przetwarzania danych (www.dc.talex.pl [data dostępu: maj 2013]).

3. Działań związanych z internetem:

ÿ fejsować - publikować na portalu społecznościowym www.facebook.com;

ÿ instagramować - publikować na portalu www.instagram.com;

ÿ wygooglować - wyszukiwać przez pomocy wyszukiwarki internetowej www.google.com.

W przypadku dwóch zapożyczeń widoczna jest świadomość metajęzykow użytkowników. W przypadku zapożyczenia carpooling na blogu toczyła się dyskusja o tym, czy nie powinno się stworzyć polskiego odpowiednika dla tego wyrazu. J ednak osoba, która reprezentowała firmę zajmującą się carpoolingiem, przyznała, że od lat prowadzone są działania mające na celu wprowadzenie tego słowa do języka polskiego, ponieważ carpooling ma za zadanie łączenie ludzi $\mathrm{z}$ róźnych krajów, a więc za wygodniejsze uznano używanie wspólnej nazwy we wszystkich językach narodowych. Natomiast odnośnie frazy cloud computing, twórca bloga zauważył, że istnieje jej polski odpowiednik - chmura obliczeniowa, jest on jednak niechętnie używany przez Polaków.

Drugą co do wielkości grupą są kalki językowe, czyli zapożyczenia, w przypadku których przeniesiona zostaje struktura wyrazu lub frazy, która zostaje zastąpiona elementami rodzimymi. Najlepszym przykładem jest tutaj internet rzeczy, który na tym samym blogu jest używany naprzemiennie ze swoją angielską formą: Internet of Objects. Innym przykładem zapożyczenia z tej grupy może być e-handel (ang. e-trading), w przypadku którego struktura wyrazu jest dokładnie taka sama jak w języku-dawcy, a wypelniona jest elementami zjęzyka-biorcy.

W małej grupie zapożyczeń sztucznych, czyli tworzonych z obcych cząstek składowych, znalazł się wyraz tabfon. J est to urządzenie, którego nazwa jest połączeniem słów smartphone oraz tablet. Pierwsza część wyrazu zachowała pisownię angielską, natomiast druga - fon, została przejęta już $\mathrm{w}$ wersji spolszczonej. Bardzo podobnie jest $\mathrm{w}$ przypadku zapożyczenia smartfon. Dla tego zapożyczenia w badanym materiale znaleziono również alternatywną pisownię: smartphone. $W$ tym przypadku uznano tę jednostkę za zapożyczenie właściwe, ponieważ jest ona w całości przejęta z języka angielskiego.

Przyjęta w prezentowanych badaniach definicja operacyjna zapożyczenia właściwie wyklucza badanie pożyczek semantycznych. W badanym materiale jednak naszą uwage zwróciło słowo tablet, które w znaczeniu pojawiającym się na badanych blogach ma właśnie charakter zapożyczenia semantycznego. Zostało odnotowane w SJP, jednak jego znaczenie jest inne niż to, w którym używane jest na blogu. Według SJP tablet to urządzenie używane zamiast myszki do komputera. J ednak wraz z powstaniem nowych technologii, powyższa definicja odnosi się jedynie to 
Anna Mękarska, Victoria Kamasa: Modowe freaki i backpakerzy. Najnowsze anglicyzmy na polskich blogach

tabletu graficznego (http://www.techfanatyk.net [data dostępu: maj 2013]), a samego słowa tablet używa się w stosunku do określenia przenośnego komputera osobistego wzorowanego na laptopie (http://www.techfanatyk.net [data dostępu: maj 2013]). W związku z powyższym, można stwierdzić, że do tego słowa dodano nowe znaczenie, przez co można zakwalifikować je jako zapożyczenie semantyczne. J ednocześnie należy zaznaczyć, że w badanym korpusie może występować więcej zapożyczeń semantycznych, które jednak ze względu na przyjętą definicję operacyjną nie zostały tutaj omówione.

Ostatnią grupę stanowią zapożyczenia, których przynależność do któreś z omawianych kategorii można uznać za wątpliwą. Dotyczy to między innymi następujących przypadków:

ÿ modowe freaki - jest to połączenie zapożyczenia właściwego (część: freak) z kalką wyrażenia: fashion freak;

ÿ szybki fast food - sama fraza fast food, oznaczająca szybkie jedzenie przygotowane w gotowych, przetworzonych półproduktów, istnieje w języki polskim i jest odnotowane przez SJ P. Użyta jednak zostaje kontekście nasuwającym wniosek, że w języku polskim używa się tego słowa raczej do określenia jedzenia podawanego w barach szybkiej obsługi, a pierwotne znaczenie słowa fast zostało zatracone. Możliwe jest również, że autor tekstu popelnił błąd językowy, a wówczas frazy szybli fast food nie można uznać za zapożyczenie spelniające kryteria przyjmowane $\mathrm{w}$ niniejszych badaniach;

ÿ złapać flow - wyraz flow jest zapożyczeniem właściwym pochodzącym z języka angielskiego, nie istnieje jednak w tym języku odpowiednik frazy złapać flow. Nie znając więc pochodzenia całej frazy, trudno przyporządkować ją do którejś z kategorii.

\subsection{Podział zapożyczeń ze względu na stopień przyswojenia}

Nieodłącznym procesem wprowadzania zapożyczeń do języka jest ich przyswajanie i dopasowywanie do norm języka-biorcy. Zgodnie $\mathrm{z}$ proponowanym przez Haugena (1968) podziałem zapożyczeń ze względu na stopień ich przyswojenia w badanym materiale wyróżniono:

ÿ Cytaty (wtręty) - 43 zapożyczenia (38\%);

ÿ Zapożyczenia częściowo przyswojone - 62 zapożyczenia (54\%);

ÿ Zapożyczenia całkowicie przyswojone - 9 zapożyczeń (8\%). 


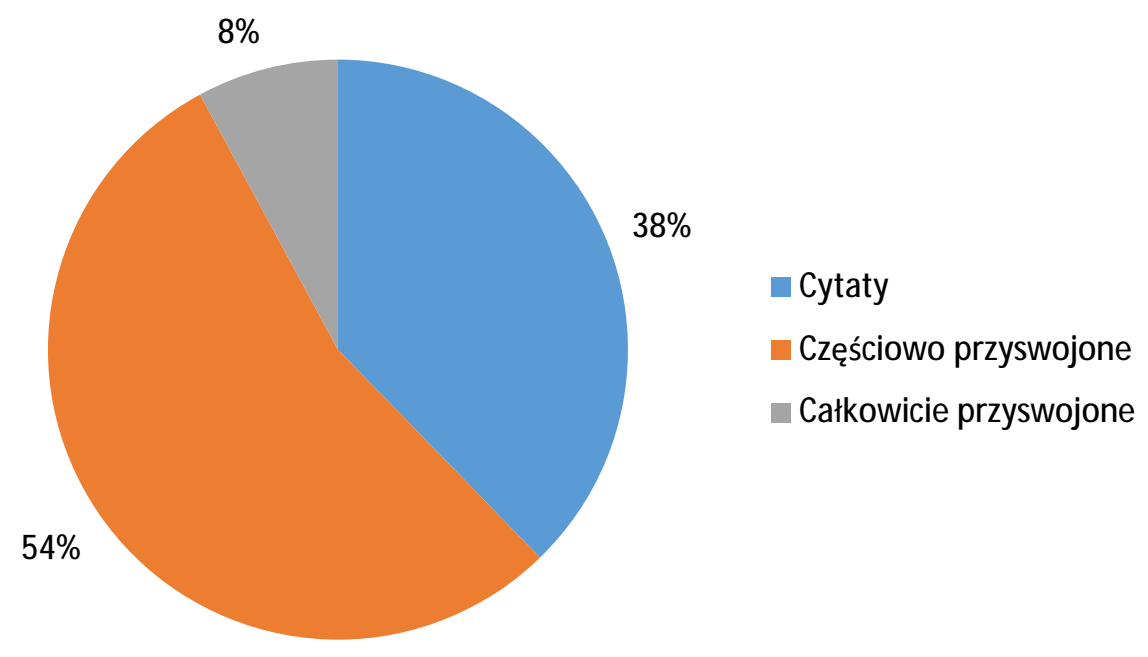

Wykres nr 2.: Podział zapożyczeń ze względu na stopień przyswojenia.

Największą grupę stanowią zapożyczenia częściowo przyswojone. W tej grupie znalazły się między innymi:

$\ddot{y}$ fejs ( ang. face, skrót od facebook),

ÿ hejt (ang. hate, pol. nienawiść ),

$\ddot{y}$ hejterzy (ang. haters, pol. ludzie wypelnieni nienawiścią).

Wyrazy, które należą do tej kategorii najczęściej przyjęły polską pisownię, lecz zachowały obce brzmienie. O zaliczeniu do tej kategorii decydował również fakt, że autorzy badanych blogów używali ich w formach odmienionych. Do omawianej grupy zaliczono również frazy takie jak: smartphone, hostowanie czy OFFy. Zapożyczenie smartphone posiada oryginalną pisownię, zostało jednak odmienione przez twórcę bloga. Z kolei ostatnie zapożyczenie jest szczególnie warte uwagi, ponieważ jest również jednym z przykładów przechodzenia z cytatu do zapożyczenia Częściowo przyswojonego. W SJ P występuje słowo OFF, jednak według słownika wyraz ten występuje tylko w liczbie pojedynczej, natomiast na blogu został użyty w liczbie mnogiej. J est to więc przykład pokazujący rozwój języka i proces adaptacji do polskiego systemu morfologicznego.

Drugą dużą grupę zapożyczeń stanowią cytaty, które zostały użyte w swojej oryginalnej wersji i nie zauważono żadnych elementów wskazujących na zaadaptowanie do polskiego systemu morfologicznego. Przykładami z tej grupy mogą być:

ÿ cloud networking (pol. chmura obliczeniowa)

$\ddot{y}$ total black (pol. całkowicie czarny)

$\ddot{y}$ off-the-record (pol. nieoficjalnie, poufnie)

W tej grupie znajdują się największa liczba zapożyczeń, które mają swój polski odpowiednik: 
Anna Mękarska, Victoria Kamasa: Modowe freaki i backpakerzy.

Najnowsze anglicyzmy na polskich blogach

ÿ skill - (pol. umiejętność)

$\ddot{y}$ data center - (pol. centrum danych)

ÿ na backstage'u6 - ( pol. za kulisami)

Przyczyn takiego zapożyczania może być wiele. Za prawdopodobne w tym przypadku można uznać to, że autorzy tekstów chcą brzmieć bardziej profesjonalnie.

Najmniejszą grupę stanowią zapożyczenia całkowicie przyswojone. Przykładami z tej grupy są: smartfon, który zaadaptował się zarówno w polskiej morfologii jak i fonologii, czy fejsować (publikować na facebooku).

\subsection{Podział zapożyczeń ze względu na części mowy}

Pośród 114 zapożyczeń wyróżniono:

ÿ Rzeczowniki (N) - 61 zapożyczeń (53,5\%);

ÿ Frazy rzeczownikowe (NP) - 38 zapożyczeń (33,3\%);

ÿ Czasowniki (V) - 4 zapożyczenia (3,5\%);

ÿ Przymiotniki (Adj) - 3 zapożyczenia (2,6\%);

ÿ Frazy czasownikowe (VP) - 3 zapożyczenia (2,6\%);

ÿ Przysłówki (Adv) - 2 zapożyczenia (1,75\%);

ÿ Frazy przymiotnikowe (AdjP) - 2 zapożyczenia (1,75\%).

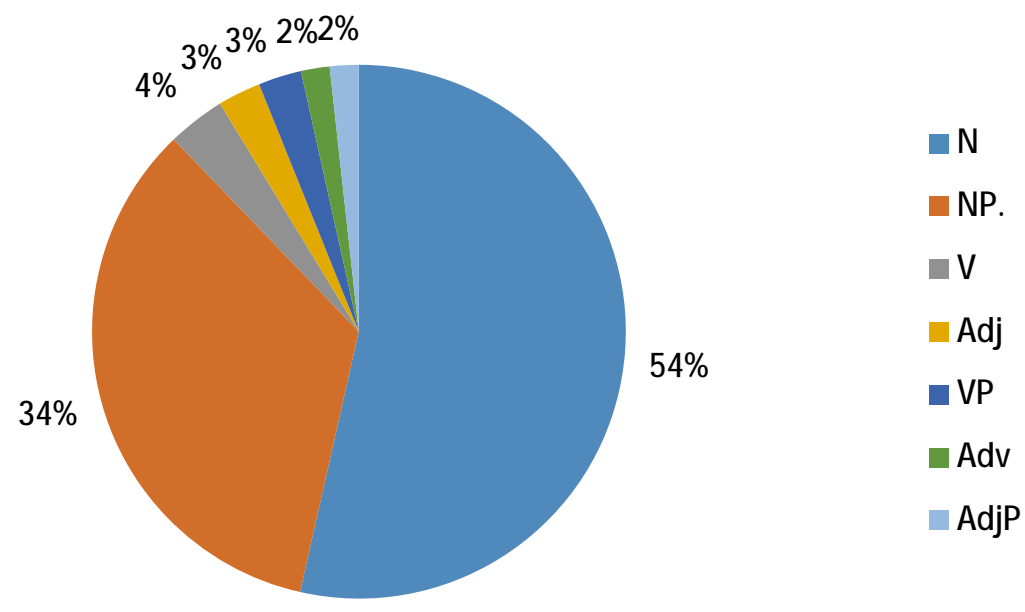

Wykres nr 3.: Podział zapożyczeń ze względu na części mowy.

Największe grupy w badanym materiale stanowią rzeczowniki i frazy rzeczownikowe. Rzeczownik służy do nazywania rzeczy, obiektów, miejsc, zjawisk, pojęć abstrakcyjnych itp. Stąd też można wywnioskować, że

${ }^{6}$ Mimo, że wyraz ten posiada ślady adaptacji do polskiego systemu morfologicznego (cząstka 'u) został on zaliczony do cytatów, ponieważ stosowana tu odmiana jest charakterystyczna raczej dla nazw obcojęzycznych niż przyswojonych zapożyczeń. 
autorzy blogów często używają zapożyczeń, ponieważ brakuje nazw dla nowych obiektów. Za przykład mogą tu służyć smartfon, ultrabook, czy startup. Podobnie funkcjonują frazy rzeczownikowe: win-win-win, hasta copywriterskie, media mainstreamowe. Można również zauważyć, że w przypadku fraz rzeczownikowych, zwykle angielskie odpowiedniki są krótsze niż ich polskie wersje:

$\ddot{y}$ win-win-win - sytuacja, w której nie ma przegranych;

ÿ hasła copywriterskie - hasła autorów tekstów reklamowych;

$\ddot{y}$ media mainstreamowe - media powszechnie akceptowane/ dominujące środki masowego przekazu.

W tym przypadku proces zapożyczania można więc tłumaczyć ekonomią językową, czyli dążeniem do tego, aby można było nadać komunikat jak najszybciej i wjak najkrótszej wersji.

W przypadku czasowników najlepszym przykładem jest zapożyczenie wygooglować. W języku angielskim od dłuższego czasu używane jest już słowo google w formie czasownikowej, oznaczające wyszukiwanie w przy pomocy wyszukiwarki internetowej Google. Od kiedy zjawisko to pojawiło się w Polsce, tutaj równiė̇ zaistniała potrzeba stworzenia słowa odpowiadającemu tej czynności. Sformułowanie „wygoogluj to” jest, ze względu na ekonomię językową, prawdopodobnie wygodniejsze w użyciu niż fraza „wpisz to w wyszukiwarkę”.

Przykładem zapożyczenia przymiotnikowego może być copywriterski, odnoszący się do copywriter (określenie autora tekstów reklamowych), czy lifestylowy, od słowa lifestyle (styl życia). Również w tym przypadku angielskie zapożyczenia są znacznie krótsze niż ich polskie odpowiedniki (związany z twórcą tekstów reklamowych, odnoszący się do stylu życia).

W przypadku fraz czasownikowych jako przykłady moga posłużyć: pay with a tweet (pol. odpłać się tweetem), pay with a post (pol. odpłać się postem). Frazy te nie mają jeszcze swoich polskich odpowiedników, prawdopodobnie dlatego też zostały zapożyczone.

Jedynym przykładem pożyczki przysłówkowej w badanym materiale jest wyraz whuteva, który pochodzi od angielskiego słowa whatever, oznaczającego obojętnie. W przypadku frazy przymiotnikowej można wskazać określenie tiffany blue, który - jak podaje autorka bloga, jest nazwą jednego $\mathrm{z}$ odcieni niebieskiego (jest to zastrzeżony przez firmę Tiffany\&Co kolor jajka składanego przez drozda o jasno-średnio niebieskim odcieniu (en.wikipedia.com [data dostępu: maj 2013])).

\subsection{Podział zapożyczeń ze względu na pola semantyczne}

114 odnalezionych w badanym materiale zapożyczeń przypisanych zostało do 10 pól semantycznych. Należą do nich: biznes, nowe technologie i informatyka, portale społecznościowe, stany rzeczy, moda i kosmetyki, kolorystyka, gastronomia, kontakty międzyludzkie, podróże oraz film. Ilościowy rozkład zapożyczeń prezentuje wykres nr 4: 
Anna Mękarska, Victoria Kamasa: Modowe freaki i backpakerzy.

Najnowsze anglicyzmy na polskich blogach

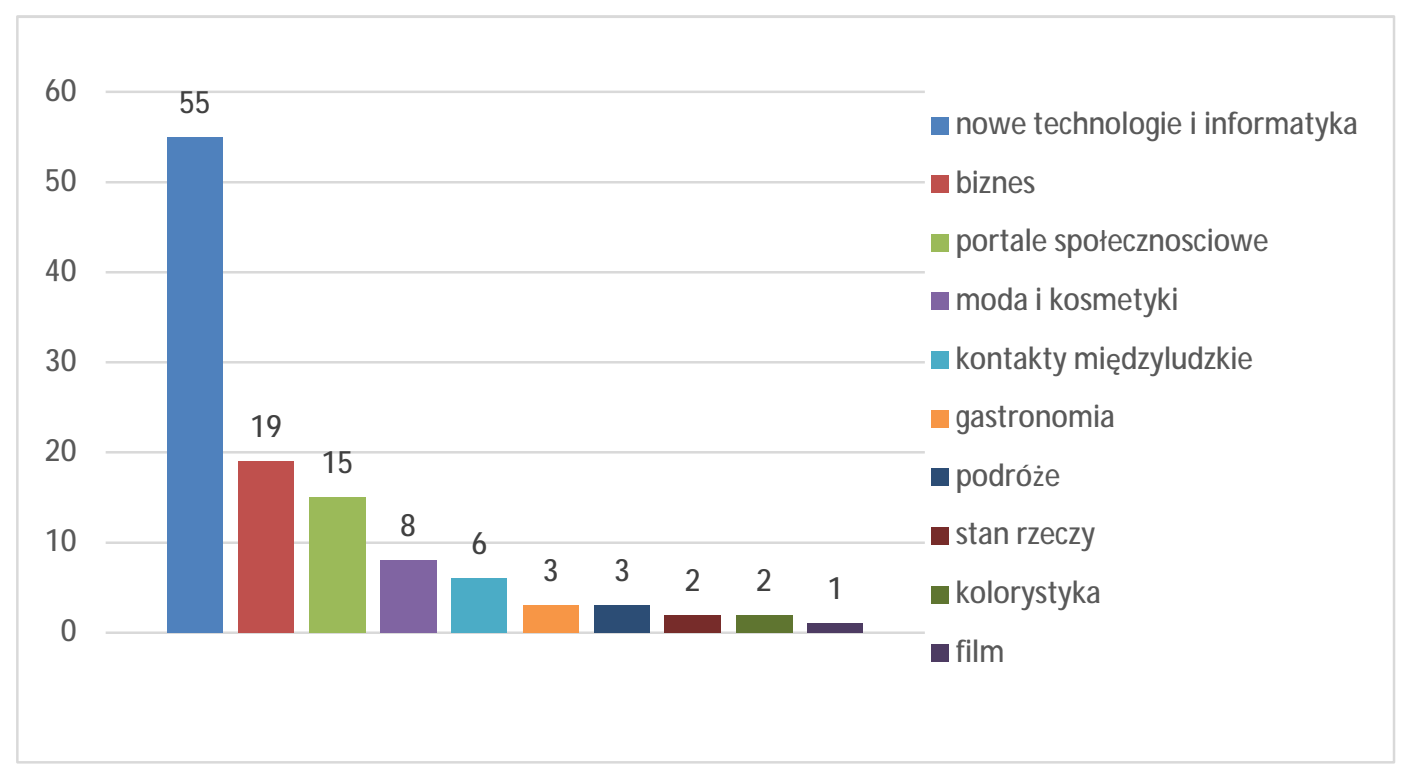

Wykres nr 4.: Podział zapożyczeń ze względu na pola semantyczne.

Największą grupę stanowią zapożyczenie związane $\mathrm{z}$ nowymi technologiami i informatyką. Zapożyczenia związane $\mathrm{z}$ biznesem oraz portalami społecznościowymi to kolejne dwie duże grupy, do których zaliczone zostało więcej niż 10 elementów. Rozkład zapożyczeń na poszczególnych blogach wskazuje na zależność pomiędzy występowaniem zapożyczeń $\mathrm{z}$ określonych pól semantycznych a tematyką blogów: zdecydowana większość zapożyczeń jest ściśle związane $\mathrm{z}$ tematami poruszanymi w postach.

Jak już wspomniano, największą grupę stanowią zapożyczenia dotyczące informatyki, technologii i procesów jej towarzyszących. Do tej grupy zaliczone zostały między innymi:

$\ddot{y}$ hostowanie plików - udostępnianie przez dostawcę usług internetowych zasobów (www.superhost.pl [data dostępu: maj 2013]);

ÿ backupy - kopia bezpieczeństwa (www.wikipedia.org);

$\ddot{y}$ motion-capture - rodzaj techniki zapisywania obrazu;

$\ddot{y}$ tabfon;

$\ddot{y}$ smartfon;

$\ddot{y}$ audiobook.

Pojawiające się w badanym materiale zapożyczenia wskazują również, że ich autorom brakuje nazw dla wielu urządzeń, które dopiero pojawiły się na polskim rynku, w związku $\mathrm{z}$ tym odnosząc się do nich sięgają po zapożyczenia.

Popularne zapożyczenia dotyczą także sferze biznesowej:

ÿ startup - (pol. początkujący biznes);

ÿ marketplace - (pol. targowisko); 
$\ddot{y}$ cross-promocja - (pol. promocja krzyżowa).

W tyle nie pozostają portale społecznościowe, które bija rekordy popularności i na ich potrzeby tworzone jest wiele nowych słów. W tej grupie znalazły się zapożyczenia takiejak:

$\ddot{y}$ opcja tagowania (pol. opcja oznaczania);

$\ddot{y}$ fanpage (pol. fanklub);

$\ddot{y}$ Fejs.

Jak wspomniano wcześniej, wiele zapożyczeń jest bezpośrednio związanych z tematyką bloga. I tak zapożyczenia dotyczące mody (modowe freaki, pol. modowe dziwaki; moda streetowa, pol. moda uliczna) pojawiają się tylko na blogach związanych z modą. Natomiast zapożyczenia dotyczące podróży pojawiają się wyłącznie na blogu poświęconemu podróżom (czekin - ang. check-in, pol. zameldowanie się, backpacker pol. turysta wędrujący w plecakiem).

\subsection{Blogosfera}

Dodatkową grupę stanowią zapożyczenia bezpośrednio związane $\mathrm{z}$ blogami. Wyrazy te wystąpiły licznie niemalże na każdym blogu, dlatego też zdecydowano się omówić je osobno. Uwagę zwraca, że żadne z nich nie jest odnotowane w SJ P. Do grupy tej należą:

ÿ bloger - 90 wystąpień

$\ddot{y}$ blogosfera - 22 wystapienia

ÿ blogować - 9 wystąpień

ÿ blogowy - 6 wystąpien

Warto podkreślić, że tak liczne występowanie jednostek związanych z blogami jest raczej uwarunkowane pochodzeniem badanego materiału, niż ogólnymi tendencjami dotyczącymi zapożyczeń.

\section{Podsumowanie}

Zgromadzony materiał badawczy pokazuje, że najbardziej wpływowi polscy blogerzy dosyć chętnie używają anglicyzmów. Przejawiają oni również dużą kreatywność w ich tworzeniu. Na każdym z badanych blogów znalazł się przynajmniej jeden anglicyzm, a w całym korpusie znaleziono wszystkie typy zapożyczeń. Zgodnie z tendencją odnotowaną do tej pory w literaturze (np. Muysken 1981) najczęściej zapożyczane są rzeczowniki. Zauważono również pewne zależności pomiędzy tematyką bloga, a liczbą zapożyczeń na nim występujących.

Należy jednak pamiętać o pilotażowym charakterze opisywanego badania: liczba blogów poddanych badaniu jest zbyt mała, aby móc prowadzić jakiekolwiek generalizacje dotyczące tych zależności. Przeprowadzenie dalszych badań mogłoby umożliwić znalezienie tych zależności oraz dokładniejszy ich opis. Powyższe badania przedstawiają więc jedynie małą część zapożyczeń używanych na blogach, mogą jednak stanowić podstawę do dalszych badań. 
Anna Mękarska, Victoria Kamasa: Modowe freaki i backpakerzy. Najnowsze anglicyzmy na polskich blogach

Według badań CBOS z 2012 roku, niemal 30\% internautów czyta blogi, z czego 50\% to najmłodsi użytkownicy - czyli ludzie, których język ciągle się ksztaltuje (Ożóg 2012). Można więc przypuszczać, że blogi mają wpływ na ich polszczyznę co jest kolejnym powodem do dalszego badania tego zjawiska.

\section{Bibliografia:}

Crystal, D. 2006. Language and the Internet. Cambridge, UK: Cambridge University Press.

Doroszewski, W. (red.) 1958-69. Stownik języka polskiego. Warszawa: Wydawnictwo Naukowe PWN.

Doroszewski, W. (red.) 1980. Stownik poprawnej polszczyzny. II. Warszawa: Wydawnictwo Naukowe PWN.

Feliksiak, M. 2012. Korzystanie z intenretu. Centrum Badania Opinii Społecznej (źródło: www.cbos.pl (dostęp: maj 2013).

Fisiak J. 1962a. Złożony kontakt językowy w procesie zapożyczania z języka angielskiego do polskiego, Język Polski XLII nr 4, pp. 286-294

Fisiak J. 1962b. Kategoria rodzaju rzeczowników zapożyczonych z języka angielskiego. Sprawozdania Komisji J ęzykowej ŁTN 9, pp. 63-68.

Fisiak, J. 1969. The Semantics of English Loanwords in Polish. Volume Studia Anglica Posnaniensia, Issue 2, pp.41-50.

Gołąb, Z., Heinz, A., Polański, K. 1968. Stownik terminologii językoznawczej. Warszawa: Wydawnictwo Naukowe PWN.

Haugen, E. 1950. The analysis of linguistic borrowing. Language, 1950 (26), pp. 210- 231.

Kawka, M. 2010. Blog jako gatunek dziennikarski, ewolucja i transgresja. w: K. Wolny-Zmorzyński, W. Furman (red.) Internetowe gatunki dziennikarskie. Warszawa: Wydawnictwa Akademickie i Profesjonalne, pp.61-69.

Kozanecki, P. 2010. Wykorzystanie blogów politycznych w dziennikarstwie internetowym. w: K. Wolny-Zmorzyński, W. Furman (red.). Internetowe gatunki dziennikarskie. Warszawa: Wydawnictwa Akademickie i Profesjonalne, pp. 80-86

Maj, A. 2010. Dziennikarstwo społeczne jako nowy trend w kulturze. w: K. Wolny-Zmorzyński, W. Furman (red.). Internetowe gatunki dziennikarskie. Warszawa: Wydawnictwa Akademickie i Profesjonalne, pp. 119-127.

Muysken, P. 1989. Language Contact and Bilingualism. Amsterdam: Amsterdam Univeristy Press.

Myers, G. 2009. Discourse of Blog and wiki. London, New York: Continuum (Continuum discourse series).

Olszański, L. 2006. Dziennikarstwo internetowe. Warszawa: Wydawnictwa Akademickie i Profesjonalne.

Ożóg, K. 2002. Kod ograniczony wśród współczesnej polskej młodziėzy. Horyzonty polonistyki 2002 (9), pp. 521- 524.

Sobczak, J. 2010. Granice wolności internetowych gatunków dziennikarskich. w: K. Wolny-Zmorzyński, W. Furman (red.) Internetowe gatunki dziennikarskie. Warszawa: Wydawnictwa Akademickiei Profesjonalne, pp.180-194.

Stępkowska, A. 2011. English loanwords in Polish naval vocabulary. Wrocław: Polska Akademia Nauk. 
Szpila, G. (red.) 2002: J ęzyk trzeciego tysiąclecia. Zbiór referatów z konferencji: Kraków, 28 lutego - 2 marca 2002. Kraków: Tertium.

Thomason, Grey S. 2001.Language contact. Edinburgh: Edinburgh University Press.

Thomason, Grey, S., Kaufman, T. 1991. Language contact, creolization, and genetic linguistics. Berkeley: University of California Press.

Tomczyk, T. 2013. Najbardziej wpływowi blogrzy Polski w 2012 r. źródło: http:// www.kominek.in/2013/01/ najbardziej-wplywowi-blogerzy-polski-w2012-r/ (dostęp: luty 2013).

Wiśniewska-Białas, H. 2011. Wpływ języka angielskiego na polszczyznę blogów. Warszawa: Wydawn. Uniwersytetu Warszawskiego.

Witaszek-Samborska, M. 1992. Wyrazy obcego pochodzenia we wspótczesnej polszczyźnie. Na podstawie stowników frekwencyjnych. Poznań: Wydawnictwo Nakom.

Wolny-Zmorzyński, K., Furman, W. 2010. Internetowe gatunki dziennikarskie. Warszawa: Wydawnictwa Akademickie i Profesjonalne.

Zdunkiewicz-J edynak, D. 2008. Spolszczony angielski czy zangielszczony polski? Wpływ języka angielskiego na język generacji gadu-gadu. The Linguistic Guide, pp. 50-61.

\section{Źródła internetowe:}

www.dc.talex.pl. - data dostępu: maj 2013

www.en.wikipedia.com - data dostępu: maj 2013

www.intel.pl - data dostępu: maj 2013

www.superhost.pl - data dostępu: maj 2013

www.techfan.pl - data dostępu: maj 2013

www.wolnelektury.pl - data dostępu: maj 2013

www.slownik-synonimow.eu - data dostępu: maj 2013 